\title{
Research on Leading Strategies and Approaches to Rational Patriotism of New-Period College Students
}

\author{
Fang-bing Meng \\ The state-owned assets management department of Wuhan University of Technology
}

\begin{abstract}
Now, the nationalism is prosperous and the nationstate consciousness of Chinese people is increasingly enhancing. Under this background, we scientifically analyze the Chinese reality, further dissect the growing ideological trend of Chinese nationalism, expose its nature and expound in depth the materials and lessons drawn from it. It has distinctive significance to implementing patriotic education among college students and leading the public to practice rational patriotism and further carrying forward patriotism.

Index Terms - nationalism ideological trend, college students, patriotism
\end{abstract}

\section{Introduction}

Presently, nationalism has become a major power in the contemporary international politics as well as an unprecedented political wave. It exerts more obvious influence on the whole world and each country and plays still further an important ideological role of the times. What we should take seriously is that "all nationalism is the reflection of its national character". The national character of a country is symbolized by patriotism and national will, which demonstrate the national cohesive force and the integrity of the country. With the improvement of Chinese comprehensive national power and the more frequent international interaction, it is necessary to strengthen the nation-state consciousness of Chinese people, especially college students who should be educated to draw materials and lessons from contemporary nationalism and choose rational patriotism with resolution.

\section{Patriotism under the Influence of Contemporary Chinese Nationalism Ideological Trend}

Since the new century, also the times when globalization has greater and deeper influence on China, nationalism gradually has accumulated it power in China. Nationalism ideological trend exerts its influence on Chinese public in the field of political psychology and its influence is mainly manifested as an intense patriotism:

1) Love and loyalty to the country expressed by the general public who are represented by the youth. In 1999, American army bombed Chinese embassy stationed in Yugoslavia. Chinese people under the lead of college students held parade against America. At then, the nationalism of Chinese youth and Chinese public has reached its peak. It is indicated in the magazine 2003: See the World by Chinese Youth, that Japan and USA are the least friendly countries to China in the eyes of Chinese youth surveyed, on the other hand, France is regarded as the country who has the most favorable feeling to China while Russia who is the most friendly to China. As for the problem of "independence of Taiwan", overwhelmingly $84 \%$ of Chinese youth agree to "defend the unity by force" if Taiwan dare to "declare independence". Meanwhile, $83 \%$ of Chinese youth think "it is necessary to enhance China's military power".

2) Intense appeal to maintaining national benefits and reviving national culture. The rise of Chinese nationalism is the result of searching the developing and growing power on the way of opening up and reform. It embodies people's mental appeal to national benefits and national culture revival. Since the opening up and reform, China's comprehensive national power has increasingly enhanced. Chinese people have more confidence in China's international status and image and held realistically profound perception of international relations. Chinese people have pushed waves one after another in maintaining national benefits and reviving traditional culture. In the case of promoting "Confucian culture" to the world, since the establishment of the first Confucius Institute in South Korea, the Confucius Institute (including Confucius schools) has covered up to 88 countries and areas and its number has reached more than 280 .

3) Radical and even extreme nationalism. The main features of it are as follows: 1) hold one-sided knowledge of the history and reality of our nation, Western nations (including Japanese nation) and Sino-Western national relations, deep-rooted prejudice produced from false information, based on which their emotions and judges are formed; 2) supervise and understand current international relations with outdated and rigid theories; 3) express their loyalty to this nation and country in the way of being deeply xenophobic. There are diverse speeches of nationalism, which consist of both rational appeals to focusing on national benefits in international relations and national expansionism which threatens to start war; both appeals to respecting and reviving China's traditional culture and radical ideas of founding extreme equality out of social inequality. Intense mood of anti-Japan and anti-USA and deep anxiety of China's national benefits are the common features of them. These speeches have their moral legitimacy because of these common features. Any doubt and censure about them will be regarded by nationalists as betrayal to the nation and country and will be censured morally.

About the author: Meng Fang-bing, male, born in Qishan, Shaan Xi Province in February 1977. Associate Professor of Marxism School, Wuhan University of Technology, Postgraduate supervisor and doctor of Management. Research orientation: Ideological and Political Education. 
Among the three forms of patriotism, the former two are healthy and rational nationalism, which reside among the ordinary public and have positive meaning to the development of China. On the contrary, the latter one is aggressive, xenophobic and irrational nationalism, and its extremity will result in separation of nation. The latter one holds distinctively dominant place in the media for it is the most active and often holds the banner of "patriotism" and has great deception. Meanwhile, youth students and intellectuals account for a large proportion in its main body. Therefore, in the situation of extreme nationalism, we must keep alert and should draw experiences and lessons from the contemporary nationalism and form right patriotic ideology.

\section{Essential Differences between Nationalism and Patriotism}

Nationalism has enormous charisma and influence. It exerts tremendous demonstrative effect on other countries and nations due to its success in the construction of Western European countries. During the course of unique political changes of contemporary China, the in-time change of nationalism and patriotism from traditional to modern has become the most effective social mobilization materials which will cohere with public feelings and integrate social ideology. During such a course of presentation, while patriotism and nationalism have unique patterns of manifestation and their own means of expression, there exist contradictory situations between them. However, since modern times, nationalism has become the reality and the potential mainstream ideology. Nationalists present their self-awareness and national sentiments in the schema of patriotism, which has become a political conduct. Patriotism and nationalism benefit from each other and supplement each other. Which are manifested as the dynamic communication and static homogeny based on the common state benefits and become the foundation of people's conviction. While nationalism is the highest manifestation of national awareness, patriotism is the highest manifestation of country awareness. Nationalism usually has dual nature:

One is the nationalism within normal limits, a kind of social ideology that is legitimate and reasonable and that is bound to exist. Seen from the current international situation, economical globalization has brought about the assimilation of production modes and lifestyles between different countries all over the world. This assimilation didn't bring world commonwealth, instead, it has undermined some countries' interests, especial developing countries. It also imposed intense impact on their inherent culture and tradition. Many new features, such as neo-imperialism, neo-conservatism and unilateralism, etc. have derived from American hegemony, which always increases but never decreases its power and which has posed great challenges to the current international law system and other sovereign states. The world safety situation is not optimistic. Many countries, like USA, Britain, Japan and Russia, etc. have adopted strategies of forestalling the enemy, which added more unsafe elements to the current international situation which is not peaceful now. In such international situation, people who have formed slavish mentality and comprador concept during the course of opening up and reform will overly derogate their own nation and deny their own tradition, while they try their best to boast national nihilism, advocate criteria of Western values and greatly undermine national interests. This is the dissimilation of opening up and reform and has totally deviated from the original intention of opening up and reform. Under such circumstances, contemporary Chinese nationalism ideological trend manifests their deep sentiments toward China and their determent attitude toward national interests. It can promote the sense of national pride and self-confidence of Chinese people. It can also mobilize, call on and cohere with our national power toward the great dream in big strides. It is the bond to cohere with and integrate the national power and spirits.

The other is the irrational nationalism beyond normal limits. This kind of nationalism cannot manifest patriotism. Instead, it can easily endanger the country. There are some defects in the theory of nationalism ideological trend, which holds the idea that most of the current problems facing China are from the basic historical orientation and fundamental realities of the country of "late development". What's more, it is believed that the suppression and plundering of developing countries by international capital during the process of globalization are the major reasons of worsening developing countries. The worst belief is that all problems of China are the results of American hegemony and powerful politics. Nationalists regard American culture as "one-time", against nature and against humanity. They also think that American culture is the entire dissimilation sample of human civilization and it is worthless and has no prospect. This reflects a kind of national narrow-mindedness. If we let this kind of national mood develop further, and it will ignite the suppressed passion hidden in people's hearts until it will influence government decision in the form of people's will, it will certainly be harmful to China's opening up and reform and its communication with the outside world, especially China's communication with Western countries within "the period of strategic opportunity" for a stable surroundings in the future 20 years. It is disadvantageous for China to treat the international community and the whole body of mankind with a responsible attitude. It is impossible for China to continue single-mindedly the socialism modernization construction if it is in a dangerous international surrounding with hostile neighbors and powerful rivals around and in this case, the great cause of China's rejuvenation will encounter great difficulties. Thus, it can be seen that nationalism can result not only patriotic conduct but also behaviors deviating from patriotism.

\section{Establishing Rational Patriotism among College Students}

As the universal value of human beings, the core of patriotism refers not only to the dedication and loyalty to one's own nation and country but also the respect and equality to other nations and countries in the world. Irrational nationalists or narrow-minded nationalism usually derogate and repel other 
nations and excessively accept their own nations. Currently, we should, on the one side, advocate patriotism among college students, on the other side, prevent the spread of irrational nationalism. We should grasp the nationalism ideological trend in a comprehensive and in-depth way, draw its rational elements and correct its biased parts. We should also educate and lead college students to maintain the passion of patriotism and practice patriotism in a rational way. Specifically, we should do in the following aspects:

First, we should try to balance the relations among reform, development and stability in the times of globalization under the theoretical guidance of Marxism-Leninism. We should put in time and energy in the practice of theory in association with reality and make it pertinent and practical, profound and implicit. We should persist to study the fundamental principles of Marxism-Leninism, to learn the history of China and Communist Party of China, to build up conviction in Marxism-Leninism, especially to analyze the historical and reality problems with Marxism standpoint, viewpoint and methods. Rational patriotism requires us to develop fast by catching every opportunity under the globalization background. We shouldn't be distracted by the disturbance from outside, especially by all kinds of internal and external elements which are harmful to national stability because they will mislead us into damaging the fundamental goal of China's economic development. We should keep in mind anytime that in the current society, power is the most important. As a developing country, national strategic interests and safety all depend on the national economic development and the improvement of its competitiveness. Social stability requires rational nationalism.

Second, change love toward nation and country into practical and persistent action, especially cope with contradiction and conflicts across nations with rational attitude and in a peaceful mode. "The aim of carrying out patriotic education is to lead people's patriotic passion and cohesive power into the great cause of establishing socialism with Chinese characteristics and to contribute to state unity and prosperity and to do a 'Four Haves' civics, and unite to strive for the realization of four modernizations and the common ideal of revitalizing the Chinese nation." Therefore, we should love our country in a way combined of principle and flexibility from the whole situation. We shouldn't forget that during the two world wars German nationalism had driven modern nationalism to its extremity, which changed into ethnocentrism. In the East, Japanese changed nationalism into militarism. Undoubtedly, extreme nationalism brought enormous disaster to the whole world. Taking history as a mirror, our nationalism will never go their destructive old road.
Third, while we protect national interests and national esteem, we should avoid counter-consciousness, exclusionist ideology and isolationism. We should be able to tell "healthy nationalism" from "morbid nationalism". The contents of other countries' patriotic education show emphasis on the preservation and construction of national internal culture and emphasis on national characteristics in modern society and emphasis on the acceptance and emotions of their own national culture carrier. This is a kind of positive nationalism. Nationalism will show negativity and irrationality when patriotism is established in the contradiction with the outside world. Therefore, we are required to have compatibility when we practice patriotism. On the basis of inheriting the fine tradition and excellent civilization of Chinese nation, we should have the courage to accept the universal value of human beings and vigorously initiate democracy, liberty, rule by law and human rights. We shouldn't be conservative, narrow-minded and extreme, instead, we should be openminded to absorb excellent achievements of civilization in the world to be used by us to make our country to prosper in a fast pace and make contribution to the world peace and development.

\section{Conclusion}

In the new period, we should work at further promoting national integrity and cultivate national spirit among college students and overcome all kinds of difficulties with engorged energy, spirit and expression. We should let our nationalism keep pace with the following things as the sharp rise of Chinese economy and the people's acceptance of core values. We should always remember that a country's nationalism is for good and all manifested by patriotism and national will, it embodies the national cohesive power and unity of the country.

\section{References}

[1] Chen Huiming, Liu Xiaojuan. College Patriotism Education under Waves of Nationalism. Moderners (latter half of the month ). $6^{\text {th }}$ issue 2008

[2] Shi Yunxia. Research on the History of Ideological and Theoretical Education of the Communist Party of China Since the Founding of New China. China Social Sciences Press. June, 2007

[3] Yang Kuisong. Seeing China Nationalism with Historical Eyes. $1^{\text {st }}$ issue, 2006

[4] Pang Ning, Wang Bingquan. On Nationalism Ideology. Higher Education Press. July, 2004

[5] Yang Xinsi. Culture Nationalism and Modern China. People Press. Novermber, 2003

[6] Wei Ling. Perspective of Contemporary Nationalism. Contemporary World and Socialism. $4^{\text {th }}$ issue, 2002

[7] Wang Zeying. Fusion and Interpretation of Chinese Patriotism and National Sentiments. Journal of Nan Tong Normal University (philosophical and social sciences). $2^{\text {nd }}$ issue, 2001 